\title{
A note on Earls Colne sources
}

This book, in common with other recent work on Earls Colne, is substantially based on the materials collected by Alan Macfarlane and his team of researchers in the years following I972. These materials have been published twice: first on microfiche in I980-83 (Records of an English village, Earls Colne, 1400-1750: Cambridge, Chadwyck-Healey) and more recently on a website which can be accessed through the website of the Department of Social Anthropology at Cambridge (linuxo2.lib.cam.ac.uk/earlscolne//contents.htm) or Alan Macfarlane's own web pages (alanmacfarlane.com). The website obviously has considerable advantages over the two-dimensional flexibility of the fiche, not least through its powerful indices. It is assumed that most readers and future researchers will make recourse to the Earls Colne website, with rather fewer using the fiche and virtually none the original records held in the Essex Record Office, the National Archives/Public Record Office and elsewhere.

For this reason we have elected to give only the index number to the fiche and website coupled with a description of the document and not the archival call number. The fiche index numbers take the form of a number followed by a point, followed by five further numbers, so I.00005, 672.0III7. This number is unique and refers sometimes to a single document (e.g. a will), sometimes to a single paragraph or entry within a larger document (so an admittance or presentment in a court roll). The three booklets (covering Church Records, Estate Records and State Records) which accompany the fiche contain an index to the numbers and the documents contained at each number. Reference numbers on the website are the same as those for the fiche except that the point is omitted, so 6720III7.

Whilst these numbers can be readily used to access the fiche, the website, as it is presently configured, cannot be accessed by index number alone. Instead, the user needs to have some additional information, normally the type of document, the date of the document or the 
name of a person involved in it - preferably two of the three. We have provided these to enable other researchers to find the source cited within the web site without too great a difficulty. The website also contains the full text of Josselin's diary; we have, however, cited this from the familiar edition of 1976 although it should be noticed that the website indices to the diary are superior to those in the printed volume. The website also contains post-I750 materials which are not found in the fiche (the sequences beginning 800.00000 and 900.00000) including later Earls Colne wills and the important annotated rental of the manor of 1854 .

Where an archival reference is given, it should be inferred that the document is not contained in the fiche or website.

Finally, we ought to add that we have not referenced every land transaction, but we hope that all our statements will be readily verifiable through the on-line indices. 